\title{
Finding Canada's History of Capitalism in the Work of Craig Heron
}

\author{
Jason Russell, Empire State College - SUNY
}

This article originated in a discussion that occurred a couple of years ago at a Toronto Labour Studies Group meeting. At that time, the history of capitalism movement that was emerging in the United States was mentioned and its merits were critiqued. One view - articulated by the more senior members of the groupwas that the history of capitalism in Canada had already been integrated into the work of labour and working-class historians. The implication was that there would be no utility in pursuing a new history of capitalism sub-field in Canada, similar to what was under development in the United States. There is an obvious question that arises from that day's discussion: how has capitalism appeared in labour and working-class historiography in Canada? More specifically, how has it been integrated into Craig Heron's work? This article argues that the history of Canadian capitalism has been woven throughout Craig's work, as well as the research of many of his peers and collaborators in Canadian labour and working-class history.

There is a second question that is clearly integral to this overall narrative: how does the history of capitalism relate to other historical sub-fields? The field originated in 1996 at Harvard University, when historian Sven Beckert began offering a seminar on the History of American Capitalism. The history of capitalism is frequently perceived as business history with a new name, but that is not its intent. Thinking about the history of capitalism means looking at how this type of history is found in society, culture, politics, and economics. This means looking critically at corporations, the principal manifestations of modern capitalism, and situating them within a broad analytical context. The need to place capitalism and its many forms in the forefront of historical narrative - both academic and public - has never been more pressing. Capital has always been central to Canada's development; it can rival government in influence and has often been more malevolent than benevolent it its relations with labour. A vast majority of Canadians have, since European colonization, participated in a capitalist economy that involved them selling their labour. Capitalism thus deserves frequent and vigorous critique. ${ }^{1}$

The purpose and future of labour and working-class history is germane to this discussion. Historians have widely acknowledged that the study of Canadian history has fallen out of favour with undergraduate students, yet we live in an era when the role and influence of capitalism is undergoing renewed scrutiny. For example, Piketty's detailed historical analysis of capitalism's development has received extensive public attention, illustrating the extent of popular interest in issues like wealth and inequality. ${ }^{2}$ Successful efforts to raise minimum wage rates above subsistence levels in Canada and the United States further demonstrate that people are 
willing to challenge the excesses of capitalism. ${ }^{3}$ Labour and working-class historians can contribute to these efforts by placing them within a wider context, and Craig's work illustrates how this may be accomplished.

Craig is part of a generation of historians who came to prominence when labour and working-class history was emerging as a vibrant field in North America. However, unlike his equally prominent peers, Craig did not study directly under American historians like Christopher Lasch. He instead spent a year at Warwick University in England, before returning to Canada to complete a Ph.D. at Dalhousie University. The influence of both early British and American labour historians like Edward Thompson and Herbert Gutman nonetheless resonates through Craig's work. ${ }^{4} \mathrm{He}$ is part of a cohort of historians in Canada including Bryan Palmer, Ian McKay, Joan Sangster, Greg Kealey, Linda Kealey, Ian Radforth, Franca Iacovetta, and Bettina Bradbury, who followed the footsteps of predecessors like H. Clare Pentland and Irving Abella. ${ }^{5}$ They referenced the works of their American colleagues including Alice Kessler-Harris, Leon Fink, and Stephen Meyer, and those scholars reciprocated. ${ }^{6}$ The vitality of Canadian labour and working-class history is acknowledged and celebrated in the United States. As a Canadian who now works in New York, I occasionally think about comparisons between the work of different Canadian and American labour historians-this is especially true if I know them personally. For example, in past years when Craig and I talked about American labour and working-class history, he frequently commented on Stephen Meyer's scholarly contributions. I was subsequently on a North American Labour History conference panel with Meyer, and found that he was equally enthusiastic about Craig's work.

While Craig has acknowledged, celebrated, and criticized the work of historians based in other countries, his work on labour and working-class history is firmly rooted in Canada. Craig's work is not highly theoretical, but is nonetheless consistently informed by historical materialism and class-based analysis. He prefers to focus on early industrialization in Canada and its subsequent development, especially the late nineteenth to early twentieth centuries. Craig often chooses to divide his analysis into themes, rather than chronology, and I will apply the same approach in discussing his work. I reflect here primarily on the monographs that he has written, but will incorporate some references to the books that he has edited and coauthored. Working in Steel was Craig's first book, in which he wrote about work: corporations, machines, labour, and worker resistance were all sub-themes in this analysis, and capitalism appears throughout. ${ }^{7}$ The book carefully describes the deliberate manner in which the Canadian steel industry was created, and details such as changes in production processes, the size of the industry, and national and international competition are thoroughly discussed. The formation of Canadian industry appears in subsequent work-most notably, the development of the Canadian brewing and distilling industries is as central to Booze: A Distilled History as the actual working-class experience with alcohol. The production, distribution, 
and sale of booze was the purview of corporations, and Craig's analysis in this book ably recounts the rise of major firms such as Gooderham and Worts, Seagam, Labatt, and Molson. Indeed, in 1862, Gooderham and Worts was worth more than any other industrial enterprise in Ontario. ${ }^{8}$ Working-class life was shaped by booze, and the alcoholic beverage industry was in turn shaped by its customers. This included the shaping of gender identity - principally male — through representations of how someone drinking booze should have looked and acted.

Canadian capitalism underwent enormous changes from the 1860 s into the early decades of the twentieth century. Family-owned firms like Massey, Labatt, Molson, and Eaton's either grew under the initial ownership structures or became part of larger organizations. The Canadian state supported a legal and economic framework that fostered domestic industry, which also meant ensuring that employers enjoyed disproportionate power in the workplace. Consumer culture, a creation of free-market capitalism, grew in the early twentieth century. Changes in corporate structure reflected the growth of companies owned through stocks and other financial instruments; management was in control of firms, rather than the people who actually owned them. Industrial consolidations continued in the post-World War II decades as many well-known Canadian firms became part of conglomerates. These trends all appear in Working in Steel and Booze.

The nature of academic writing is such that the work produced by earlycareer scholars is often not intended for non-academic readers. Historians understandably focus on producing a scholarly book that will hopefully establish themselves in their fields, and will think about perhaps producing a book intended for a wider audience further along in their careers. The Canadian Labour Movement: A Short History fits the latter description.' This book covers a lot of ground, and the influence of capital on Canadian workers is evident throughout. It covers changes in craft worker culture wrought by new production processes, the Workers' Revolt and the interwar period, and the emergence of the Wagner-based post-World War II labour relations system. Worker responses to state and capital are mentioned throughout. Craig's interest in the early twentieth century is again evident in The Canadian Labour Movement.

Worker agency in response to capital is a frequent theme in Craig's work. The Workers' Revolt in Canada, 1917-1925 includes contributions from several labour historians, and provides key insight into the origins and meanings of the tumultuous period of post-World War I labour militancy. ${ }^{10}$ The impact of Canadian capitalism on workers is evident throughout this volume. Problems such as work rationalization, wage inequality, and employer hostility drove worker militancy. The fact that Canadian workers in different parts of the country struggled at the same time as their comrades in other industrial nations were making similar efforts helps contextualize the post-World War I period. The Winnipeg General Strike, which is arguably the most well-known Canadian event from the Workers' Revolt period, publicly brought capital, as much as labour, to the forefront of class struggle. The 
difficulty of trying to foster militancy on a national scale in response to the power of capital is clear throughout The Workers' Revolt. As Craig notes, "However much workers in all parts of the country shared common aspirations and similar patterns of organizing in the 1917-25 period, the various working-class movements that emerged faced very different opportunities and obstacles." The problem of channeling common aspirations into enduring movements would persist well beyond $1925 .{ }^{11}$

Worker responses to the work process in Canada are the focus of On the Job: Confronting the Labour Process in Canada, which was co-edited by Craig and Robert Storey. ${ }^{12}$ This edited volume was unique because it examined the responses of workers in different stages of Canadian capitalist development and, most crucially, in a range of fields from resource extraction to service industry work. Craig and Robert Storey argue in the introduction that the contributors to On the Job "present a powerful antidote to the boundless enthusiasm about the benefits flowing from the transformation of industry." That enthusiasm has generally been effusively expressed by business and capital, and not by working people. To talk about confronting the labour process meant talking about how capitalism disrupted workplaces and working lives, and efforts to combat those changes. ${ }^{13}$

As a social historian, Craig has shown the role of capital in people's lives beyond the workplace. This perhaps is most true of The Workers' Festival, co-written with Steve Penfold. Labour Day was founded to celebrate labour's strength, to recognize workers' contributions to society, and to be a day of leisure. ${ }^{14}$ This book is unique when compared to Craig's other contributions, as it does not talk about the work process - instead, the significant impact of consumerism and the commercialization of Labour Day are described. ${ }^{15}$ Corporations may not have liked organized labour, but they were willing to profit from labour's official holiday.

The Workers' Revolt, The Workers' Festival, and On the Job were intended to provide overviews of working-class experience across Canada. Craig's research grew out of social history methodology rooted in case studies. Working in Steel, which broadly discussed the formation of the Canadian steel industry and what it meant to work in it, made frequent reference to Hamilton, Ontario and Sydney, Nova Scotia. I was aware of Craig's fondness for Hamilton before I became one of his $\mathrm{PhD}$ students and I once asked him over ten years ago "why Hamilton?" As a son of Scarborough and graduate of the University of Toronto, I thought that he would have chosen to focus on Toronto-once an industrial city. At the time Craig seemed a bit surprised or perhaps irritated by the question-I am sure that I was not the only one who posed it to him over the years — and he ultimately provided an answer in Lunch-Bucket Lives: Remaking the Workers' City. Hamilton was chosen because it was the largest of Canada's industrial centres in the early twentieth century. ${ }^{16}$ That was the officially-stated reason, but it is also my experience and observation that social historians produce truly insightful work when they are able to form a personal connection with the communities and workers that they study. This is especially 
true if they have lived working-class lives at some point.

Lunch-Bucket Lives incorporates the many themes found in Craig's preceding work - this includes the impact of capital on Hamilton, but in a far more expansive manner. The formation of Canadian capital, the work process, working-class culture, and gender are just a few of the themes found in its many pages. The discussion of the role of capital in Hamilton working life is particularly revealing. Craftwork is examined in Lunch-Bucket Lives, as it was in Working in Steel. The struggle between management and workers was about who would control the "whip hand." Managerial systems became more complex, the size and scope of companies grew in the early twentieth century, and the account of these changes is more insightful than what is found in Working in Steel. ${ }^{18}$ Workers responded through collective action, often in the form of strikes. ${ }^{19}$ Hamilton became Canada's Birmingham and Pittsburgh — a city molded by capitalist production.

The process of recounting how the history of capitalism appears in Craig Heron's work leads to two concluding questions: how does it inform the future direction of labour and working-class history in Canada, and what context can it provide for understanding the challenges currently facing workers? Craig's interest in rooting workers' struggles in relation to the means of production represented one approach to writing Canadian labour history in the 1980s. In contrast, historians like Bryan Palmer elected to emphasize the role of workers' movements while others, including Ian McKay, more fully considered the role of working-class culture. These historiographic paths were further enriched by adding race, ethnicity, gender, and regional difference into the analytic mix. The historiographic methods that scholars employ should not be considered mutually exclusive nor be ranked based by some manner of arbitrary prioritization.

I would argue that labour and working-class history needs to turn its gaze back on the workplace and workers' relations to the means of production, to better understand the roots of contention between labour and capital. The workplaces of the second decade of the twenty-first century share too many similarities with those in the second decade of the twentieth century, and there is little about this that is fortuitous for working people today. Casualized work shares many similarities with the arbitrary piecework systems of one hundred years ago. There is little difference in hoping for fleeting employment through a temporary employment agency today and standing outside the gates of Hamilton steel mill in the early twentieth century, hoping that a foreman would select you for a day's work. Moreover, struggles over the minimum wage are part of a long history of workers demanding fairer remuneration and more dignity at work.

Labour, in the broadest sense, needs labour and working-class history perhaps more than at any time in recent memory. The term "history of capitalism" need not necessarily be used, but critiques of capitalism in its varied forms should be at the forefront of historical analysis. Placing capitalism more centrally in historical analysis could include drawing upon earlier research that illustrates its role 
in Canada, by people like Abraham Rotstein and Michael Bliss. ${ }^{20}$ Workers have been losing ground and seeing their material standard of living fall since the late 1970 s. In the American context, Jefferson Cowie has recently described the decades from the New Deal to the early 1970s as an exception in American history, rather than a permanent change in direction. ${ }^{21}$ It is possible that the same conclusion could eventually be made about Canada, if problems such as income and wealth inequality are further exacerbated. It is thus prudent to place Canadian labour and working-class history within a comparative historical context. Analyses of the state of work and labour that emanate from elsewhere in the Canadian labour studies community also need to properly historicize contemporary work and employment issues, as there can sometimes be an unfortunate reflex to use limited periodization in the research.

While my work focuses on the post-World War II period, I nonetheless urge labour and working-class historians to cast a longer gaze into the past. Let us look farther back at the struggles of craft workers in Hamilton, loggers in northern Ontario, miners in Cape Breton, immigrant railway labourers in the west, and indentured servants who toiled on farms and for chartered companies. They fought to resist the worst excesses of capitalism and their struggles can help inform resistance today. It is crucial that labour and working-class history always put workers and their communities at the center of analysis. Labour history must also belong to workers as much as it belongs to the academics who write it. Workers' movements, communities, and workplaces are not populated by numbers, but by people, and this must always be emphasized in critiques of capitalism. Finally, to return to Craig's initial assertion that he and other historians had already been writing about the history of capitalism: he was absolutely correct at that Toronto Labour Studies Group meeting. His body of work will helpfully guide labour and working-class historians now and in future years, and some may even say that they also work on the history of capitalism.

\section{NOTES}

${ }^{1}$ Jennifer Schuessler, "In History Departments, It's Up with Capitalism," New York Times, April 6, 2013, http://www.nytimes.com/2013/04/07/education/inhistory-departments-its-up-with-capitalism.html (accessed May 24, 2017). For an example of Beckert's scholarship see Sven Beckert, The Monied Metropolis: New York City and the Consolidation of the American Bourgeoisie, 1850-1896 (Cambridge: Cambridge University Press, 2001). 
${ }^{2}$ Thomas Piketty, Capital in the Twenty-First Century (Cambridge, Mass: Belknap, 2014).

${ }^{3}$ For an example see The Fight for 15, http:/ / fightfor15.org/laborday/, accessed September 7, 2017.

${ }^{4}$ For representative work see Christopher Lasch, The American Liberals and the Russian Revolution (New York: Columbia University Press, 1962); Edward Thompson, The Making of the English Working Class (London: Gollancz, 1963); Herbert Gutman, Work, Culture and Society in Industrializing America: Essays in American Working-Class and Social History (New York: Knopf, 1976).

${ }^{5}$ For representative work see Bryan Palmer and Greg Kealey, Dreaming of What Might Be: the Knights of Labour in Ontario, 1880-1900 (Cambridge: Cambridge University Press, 1982); Linda Kealey, Enlisting Women for the Cause: Women, Labour, and the Left in Canada, 1890-1920 (Toronto: University of Toronto Press, 1998); Joan Sangster, Dreams of Equality: Women on the Canadian Left, 1920-1950 (Toronto: McClelland and Stewart, 1989); Franca Iacovetta, Such Hardworking People: Italian Immigrants in Postwar Toronto (Montréal: McGill-Queen's University Press, 1992); Ian Radforth, Bushworkers and Bosses: Logging in Northern Ontario, 1900-1980 (Toronto: University of Toronto Press, 1987); Ian McKay, The Quest of the Folk: Antimodernism and Cultural Selection in Twentieth-Century Nova Scotia (Montréal: McGillQueen's University Press, 1994); Bettina Bradbury, Working Families: Age, Gender, and Daily Survival in Industrializing Montréal (Oxford: Oxford University Press, 1993); H. Clare Pentland, Labour and Capital in Canada, 1650 1860 (Toronto: Lorimer, 1981); Irving Abella, Nationalism, Communism and Canadian labour: the CIO, the Communist Party and the Canadian Congress of Labour, 1935-1956 (Toronto: University of Toronto Press, 1973).

${ }^{6}$ For representative work see Alice Kessler-Harris, Out to Work: A History of WageEarning Women in the United States (Oxford: Oxford University Press, 1982); Leon Fink, Workingmen's Democracy: The Knights of Labor and American Politics (Urbana: University of Illinois Press, 1983); Stephen Meyer, Stalin Over Wisconsin: the Making and Unmaking of Militant Unionism, 1900-1950 (New Brunswick: Rutgers University Press, 1992).

${ }^{7}$ Craig Heron, Working in Steel: the Early Years in Canada, 1883-1935 (Toronto: McClelland and Stewart, 1988), 9.

${ }^{8}$ Craig Heron, Booze: A Distilled History (Toronto: Between the Lines, 2003), 91.

${ }^{9}$ Craig Heron, The Canadian Labour Movement: A Short History, 3rd ed. (Toronto: Lorimer, 2012).

${ }^{10}$ Craig Heron, ed., The Workers' Revolt, 1917-1925 (Toronto: University of Toronto Press, 1998).

${ }^{11}$ Craig Heron, "National Contours: Solidarity and Fragmentation," in The Work- 
ers' Revolt, 283.

${ }^{12}$ Craig Heron and Robert Storey, eds., On the Job: Confronting the Labor Process in Canada (Kingston: McGill-Queen's, 1986).

${ }^{13}$ Ibid., xi.

${ }^{14}$ Craig Heron and Steve Penfold, The Workers' Festival: A History of Labour Day (Toronto: University of Toronto Press, 2005).

${ }^{15}$ Ibid., 260-262.

${ }^{16}$ Craig Heron, Lunch-Bucket Lives: Remaking the Workers' City (Toronto: Between the Lines, 2015), 9.

${ }^{17}$ Ibid., 229.

${ }^{18}$ Ibid., 239.

${ }^{19}$ Ibid., 271.

${ }^{20}$ See Abraham Rotstein, ed., Beyond Industrial Growth (Toronto: University of Toronto Press, 1976) and Michael Bliss, A Living Profit: Studies in the Social History of Canadian Business, 1883-1911 (Toronto: University of Toronto Press, 1974).

${ }^{21}$ Jefferson Cowie, The Great Exception: The New Deal and the Limits of American Politics (Princeton: Princeton University Press, 2016), 9. 